\title{
Ethical Standards of Scientific Research Involving Human Subjects in Brazil: Perspectives Concerning Psychology
}

\author{
Normas de Regulamentação Ética da Pesquisa Cientifica Envolvendo Seres \\ Humanos no Brasil: Perspectivas da Psicologia
}

\author{
Selma Leitão ${ }^{\mathrm{a}}$, Jorge Tarcísio da Rocha Falcão ${ }^{\mathrm{b}}$ \& Maria Regina Maluf ${ }^{\mathrm{c}}$ \\ ${ }^{a}$ Universidade Federal de Pernambuco, Recife, PE, Brazil, ${ }^{b}$ Universidade Federal do Rio Grande do Norte, Natal, \\ RN, Brazil \& 'Pontifícia Universidade Católica de São Paulo, São Paulo, SP, Brazil
}

\begin{abstract}
Brazilian associations for research in human, social and applied social sciences have long sought ethical aspects regulation compatible with the epistemological, theoretical and methodological specificities of these sciences. Consequently, the Brazilian regulatory system (Research Ethics Committees/CEPs of the National Research Ethics Commission/CONEP) is currently undergoing an important review process. This article presents the positions taken by the National Association of Research and Postgraduate Studies in Psychology - ANPEPP. The article: (1) highlights the origins of the current ethics review model, based on biomedical research; (2) summarizes criticisms recurrent to this model; (3) identifies the directions required for the improvement of the system; and (4) lists the challenges to be overcome in the current process of creating specific regulations for the human and social sciences. The considerations presented highlight two crucial points that challenge the construction of a specific resolution for research ethics in the human and social sciences: (1) the clear characterization of what is meant by 'research in the human and social sciences' - and that would, therefore, have its ethical review regulated from the perspective of the specific resolution for the human and social sciences; and (2) the definition of parameters from which different risk levels in studies can be identified.

Keywords: research ethics, human subjects, ANPEPP Forum.
\end{abstract}

\begin{abstract}
Resumo
Associações brasileiras de pesquisas em ciências humanas, sociais e sociais aplicadas há muito reivindicam uma regulamentação de aspectos éticos que atenda às especificidades epistemológicas, teóricas e metodológicas dessas ciências. Em consequência, o sistema brasileiro de regulamentação (Comitês de Ética em Pesquisa/CEP da Comissão Nacional de Ética em Pesquisa/CONEP) passa atualmente por importante processo de revisão. O presente artigo apresenta posições defendidas pela Associação Nacional de Pesquisa e Pós-Graduação em Psicologia - ANPEPP. Em síntese, o artigo: (1) situa origens do atual modelo de revisão ética, baseado na pesquisa biomédica; (2) sumaria críticas recorrentes a esse modelo, (3) aponta direções necessárias ao aprimoramento do sistema e (4) elenca desafios a serem superados no atual processo de criação de regulamentação específica para as ciências humanas e sociais. As considerações apresentadas ressaltam dois pontos cruciais que desafiam o trabalho de construção de resolução específica para ética em pesquisa nas ciências humanas e sociais: (1) a caracterização clara do que se entende por 'pesquisa em ciências humanas e sociais' - e que, portanto, passaria a ter sua revisão ética regulada pela ótica da resolução específica para ciências humanas e sociais; (2) a definição de parâmetros a partir dos quais se possa identificar diferentes níveis de risco em pesquisas.

Palavras-chave: ética em pesquisa, sujeitos humanos, Fórum ANPEPP.
\end{abstract}

The regulatory system controlling ethical aspects in research involving human subjects in Brazil is undergoing a review process in which the human and social science research associations are seeking regulation compatible

Correspondence concerning this article should be addressed to Selma Leitão: Pós-Graduação em Psicologia Cognitiva, CFCH, $8^{\circ}$. Andar; Av. Arquitetura s/n, Cidade Universitária, Recife, PE, 50670-901. E`-mail: selma_leitao2001@yahoo.com with the methods and practices of these sciences. This article reviews key aspects of this process and presents the positions taken by the National Association of Research and Postgraduate Studies in Psychology - ANPEPP ${ }^{1}$. For this, the article highlights and develops aspects

For correspondence between names of entities in English and Portuguese see Appendix 1. 
emphasized in the Ethics Forum of the XV Symposium of Research and Scientific Exchange of ANPEPP, held in 2014. The text is organized into four sections that briefly focus on: (1) origins of the reference points of the current ethical regulatory model, based on biomedical practice and explained in CNS Resolution 466/12; (2) recurring criticisms of this model from researchers in human and social areas; (3) advances and limits perceived in the replacement of CNS Resolution 196/96 with CNS Resolution 466/12, as well as new demands arising in the context of the Forum of Human, Social and Applied Social Science Research Associations and of the Human and Social Sciences Working Group (GT) of the National Research Ethics Commission (CONEP); and (4) trends and challenges in the development of a specific resolution for research in these areas.

\section{Foundations of the current research ethics regulatory system}

Nearly two decades after Resolution 196/96 of the National Health Council (CNS) came into effect it can be observed that the review system of ethical aspects of research involving human subjects, in Brazil, has undergone considerable expansion and consolidation. In its current configuration, the system is based on two pillars. On the one hand, the principles, standards and procedures that substantiate CNS Resolution 466/12 (CONEP, 2014), the replacement for CNS Resolution 196/96, as well as the operational standards and complementary resolutions that refer to it. On the other hand, is a network of 686 Research Ethics Committees (the CEPs), distributed throughout academic institutions and research centers across Brazil. The CEPs perform an effective review of the ethical aspects of studies, a function carried out under the management and central control of the National Research Ethics Commission (CONEP) which, in turn, is subordinated to the National Health Council (CNS).

This complex and comprehensive system, commonly referred to as CEP-CONEP, is going through a delicate and critical moment. The moment is characterized by the action of a Working Group (GT) composed of a large number of research associations in Human and Social Sciences that seek and are working on the development of a proposal for specific ethical regulation for these areas (GT-CONEP). Among them are four associations from the area of Psychology: the National Association of Research and Postgraduate Studies in Psychology (ANPEPP); the Brazilian Association of Social Psychology (ABRAPSO); the Brazilian Association of Developmental Psychology (ABPD); and the Brazilian Association of School and Educational Psychology (ABRAPEE). The effort reflects and results from systematic evaluations by the academic community regarding the trajectory of the CEP-CONEP System. These evaluations have indicated serious inadequacies and limitations in the current system that does not address, or even combine with, the ethical specificities of research in human and social sciences. Therefore, the associations seek the development of new regulations, appropriate to the characteristics of these sciences.

The short history of the Brazilian system of regulation of ethics in research involving human subjects is marked by advances, challenges and persistent tensions. An aspect central to these tensions lies in the fact that in the creation of the CEP-CONEP System the perspective of biomedical research was taken as its reference. From this particular perspective, treated since then as universal, the CEP-CONEP System attributes to itself the prerogative to arbitrate on ethical aspects of research conducted in all the other fields. This unique regulatory model is expressively described by Duarte (2014) as a "troublesome wound in the current Brazilian system of science and technology." The model is marked by the unjustifiable requirement for subordination of research in human and social sciences to the concepts and procedures developed from the perspective of biomedical research, in which the center of implementation and control gravitates around the Ministry of Health.

The analysis of the hegemony of the biomedical research perspective over the other scientific research traditions practiced in Brazil requires the consideration of at least two points. First, the broader historical context that gave rise to systems of research ethics regulation around the world; and second, the references in which the current Brazilian regulation system is anchored. More generally, the emergence of evaluation systems for the ethical aspects of research was marked by two major concerns: (1) the reaction of the international scientific community to the horrors that accompanied the great wars of the last century; and (2) the recognition of human rights violations in which physicians and bio-scientists were directly involved ${ }^{2}$. The astonishment at the facts observed and the tenacious effort to prevent the recurrence of similar situations led to the reflection and regulation of ethical issues in biomedical research, which took its own objectives and procedures as a reference. The marks of this regulation, constructed from the biomedical perspective, explicitly appear in the set of documents adopted as the reference in the development of CNS Resolution 196/96 of the National Health Council (CNS). According to Guerriero and Minayo (2013), the following form part of these references: (1) the Nuremberg Code (1947), prepared in an effort to contribute to the prosecution of crimes and serious violations of human rights perpetrated by physicians and bio-scientists; (2) the Declaration of Helsinki (in its various editions) designed as a reference and guidance for biomedical clinical research;

\footnotetext{
These violations, however, are not limited to scenes of Nazi medical experiments. The history of research involving the lobotomy surgical procedure, worldwide, and especially in Brazil, illustrates this tension between motivation for the experimentation and ethical limits to be observed. Masiero (2003) reports that, in Brazil, even after the establishment of the general ethical principles for research with human subjects defined in the Nuremberg Code (1947), experimentation with patients in public mental hospitals, lasted for more than nine years. It is estimated that about 700 internal, were lobotomized only until 1949 (p. 561).
} 
(3) the ethical guidelines established by the Council for International Organizations of Medical Sciences (CIOMS) in cooperation with the World Health Organization (WHO), the research concept of which was assimilated into CNS Resolution 196/96; (4) global guidelines governing the review of ethical issues in epidemiological research; and (5) the Belmont Report (1979), which highlights the specificity of the social studies and excludes them from its scope. The Report focuses on principles and procedures directed toward the protection of research subjects in biomedical and behavioral studies.

Problems and obstacles that originate from the hegemony of the biomedical perspective in reviewing the ethical aspects in research in the human and social sciences have been repeatedly highlighted, individually or collectively, by various associations of Brazilian researchers in publications, manifestos, motions, symposia, seminars and working groups over the last two decades (Borges, 2010; Duarte, 2014; Fleischer et al., 2010; Guerriero, 2008; Guerriero \& Minayo, 2013; Guerriero, Schmidt, \& Zicker, 2008; Machado, 2012; Minayo \& Guerriero, 2014; Sarti \& Duarte, 2013). In the case of ANPEPP, positions and evaluations were constructed and made public through events (sometimes carried out in partnership with other research organizations) and documents produced by the association itself. Among the most prominent events are: the Ethics in Qualitative Health Research Meeting (Guarujá, 2006), the Ethics Forum conducted in the Symposia of Research and Scientific Exchange of ANPEPP $(2006,2008,2010,2012)$ and round tables in the annual meetings of the Brazilian Society for the Advancement of Science - SBPC in Portuguese $(2008,2010,2011,2013)$, organized in partnership with the Brazilian Anthropological Association (ABA) and/or other research organizations. Among the documents, the following should be mentioned: (1) manifesto with the repeal of the Federal Council of Psychology (CFP Resolution 016/2000); (2) the Manifesto of Fortaleza, produced in the context of the Ethics Forum of the XIII ANPEPP Symposium in 2010; ; (3) the ANPEPP/ ABRASCO (Brazilian Association of Public Health) Motion approved at the $62^{\text {nd }}$ Plenary Meeting/SBPC (2010); and (4) the Open Letter to the Ministry of Health, produced in response to the public consultation held in 2011 by CONEP, as part of the review process of CNS Resolution 196/96. The requirement for regulation that considers the epistemological, theoretical and methodological specificities of the human and social sciences is a common theme in all these events and documents.

\section{Single regulation: multiple difficulties}

The difficulties highlighted by researchers in the human and social sciences faced with the CEP-CONEP System are multiple and can be described in at least three levels.

\footnotetext{
Available at http://www.anpepp.org.br/old/XIIISimposio/Manifesto\%20
} de $\% 20$ Fortaleza.pdf.
This distinction seems to be relevant, as differences in the nature of the difficulties require different strategies to overcome them.

The first level includes complaints and difficulties relating to the operation of the CEPs. Among the most frequent complaints are: (1) delays in the evaluation of the projects; (2) interference in the research schedule; (3) extrapolation of competences, especially with regard to the methodological aspects of projects; (3) bureaucracy and "police-esque" behavior (Duarte, 2014) in the evaluations; (4) increase in the many requirements already contained in the Resolutions/CNS; (5) legalism/literalism in the reading and interpretation of the Resolutions; and (6) inconsistency among reviewers and/or CEPs in the evaluation of similar issues. Similar difficulties highlighted by researchers in psychology are described, for example, in Borges, Barros and Leite (2013) and Trinidad and Szymanski (2008). Among the aspects mentioned, the interference of reviewers and CEPs regarding the methodological issues of the projects should be highlighted. This interference draws attention due to both the frequency and the negative impact on research. The CEPs and reviewers assume that ethical and methodological aspects are inseparable. From this premise, however, they end up demanding changes in the projects, based on theoretical and methodological preferences and perspectives of their own reviewers and/or CEPs, which are not justified with regard to the effective detection of ethical problems inherent in, or resulting from the procedures used in the projects.

The second level of difficulty refers to the problems arising from the content of the Resolutions that guide the review of the ethical aspects of the studies. Two aspects are central here: (1) the concept of research on which the Resolutions/CNS are based and (2) the fact that identical procedures and requirements have been established as the framework for the evaluation of any project. In the present analysis, the content of the Resolutions requires particular attention, as it is precisely this content that needs to be reviewed and modified to meet the specific characteristics of the human, social and applied social sciences. It should be noted that criticism of the content of the Resolutions does not address the existence of regulation, but the fact that the existing Resolutions establish the biomedical framework as the only one applicable to any research. Such an approach has been considered insensitive to the specificities of the problems and to the multiple methodological perspectives that characterize research in human and social sciences. The uniformity and inadequacy of this framework lead to unreasonable general requirements. For example: constitution of samples based on statistical representativity, previous and thorough detailing of all research procedures, and obtaining the consent of the participants through their signatures in a written document (IC, TCLE in Portuguese).

The third level of tension between researchers in the human and social sciences and the current system of research ethics regulation is political in nature. It concerns 
the fact that the management of a research ethics regulation system in all and any field of knowledge has been situated, since its inception, in the context of the National Health Council, linked to the Ministry of Health. Although widely recognized as the legitimate locus of management and regulation of research in the areas of health, the CNS has been repeatedly questioned as the locus of management of the research conducted in other areas. This management is perceived, from different perspectives, as the improper and undesirable extrapolation of the competences of the CNS. The technical/academic extrapolation is most notable, given the difficulty of trained researchers within the biomedical research tradition to deal with the ethical research issues typically encountered in the human and social sciences. Therefore, there is a scarcity, or even lack of any familiarity of these researchers with the tradition of idiographic research and/or qualitative studies, in widespread use in human and social sciences. It should be noted, furthermore, that Decree No 5.839 of July 11, 2006, of the Presidency of the Republic clearly defines the duties of the CNS. According to the Decree, it is for the CNS to "accompany the process of scientific and technological development and incorporation in the health sector, aiming for the observation of ethical standards compatible with the socio-cultural development of the country" ( $2^{\text {nd }}$ Art., clause VII, emphasis added).

\section{CNS Resolution 196/96 to CNS Resolution 466/12 and new demands for the improvement of the CEP-CONEP System}

The first review of Res. 196/96 was made fifteen years after it came into force, under the initiative and management of CONEP. The review included public consultation, open from September 12 to November 10, 2011, through which (approximately) 2,000 specific suggestions and 25 other documents were received. Among the scientific associations of the human and social sciences that institutionally expressed themselves during the discussions were: ANPEPP (National Association of Research and Postgraduate Studies in Psychology), RENETO (National Network of Education and Research in Occupational Therapy), ABA (Brazilian Anthropological Association), ANPOCS (National Association of Postgraduate Studies and Research in Social Sciences) and ABEPSS (Brazilian Association of Education and Research in Social Work). Once compiled, the proposals received were discussed at the National Meeting of Research Ethics Committees (ENCEP), which provided space to preliminarily approve the text of a new resolution, subsequently enacted by the National Health Council. This resolution was designated: CNS Resolution 466/12.

The evaluations of the results obtained with the substitution of CNS Resolution 196/96 with CNS Resolution 466/12 were not unanimous. Although some researchers have argued that the new regulations led to "enormous progress," many others have identified only modest and specific progress (for example: prediction of exceptions to obtaining informed consent, admission of indirect benefits for research, and expansion of the concept of research). A frequent evaluation among researchers in the human and social sciences is that, although CNS Resolution 466/12 has brought some flexibility to aspects repeatedly identified as problematic in CNS Resolution $196 / 96$, it preserves the same perspective and general standards of biomedical research.

Two other important events, after the entry into force of CNS Resolution 466/12, confirm the need for urgent improvements in the current Brazilian research ethics regulation system. The first was the creation of the Forum of Human, Social and Applied Social Science Associations, through the joint initiative of the ABA and ANPOCS. The second was the formation, by CONEP, of a Working Group with the task of designing a proposal for a specific resolution for the human and social areas (GTCONEP). With this initiative, CONEP sought to address the provisions of chapter XIII - "Of the Resolutions and Specific Standards" -, clause XIII.3 of CNS Resolution 466/12 which states that: "The ethical specificities of research in the social sciences and humanities and of others that use the methodologies of these areas will be covered in a complementary resolution, given their particularities" (emphasis added).

\section{Forum of Human, Social and Applied Social Science Associations}

There are certainly great expectations among researchers in the human and social sciences regarding the adoption of specific ethical standards for these areas. It is understood that a resolution of ethical standards for the human and social sciences would be a considerable advance in the general practice of research in Brazil. However, despite the advances, a recurring assessment by the scientific associations of these areas is that the CNS unjustifiably extrapolates its powers in assuming the management of the review of the ethical aspects of all research involving human subjects in the country. The position widely taken by these research associations is that the regulation of research in the human and social science areas should be carried out by a specific council, under the direction of the Ministry of Science, Technology and Innovation (MCTI).

The claim for an Ethics Council under the MCTI was ratified with the launch of the Forum of Human, Social and Applied Social Science Associations, held on June 11, 2013, at the University of Brasilia. The inaugural meeting was attended by representatives of approximately 20 scientific research associations of the country. Since then,

Available at http://idor.org/comite-cientifico/nova-resolucao-466/12-regulamenta-pesquisas-em-seres-humanos-no-brasil [Accessed on 07.08.2014] 
the Forum has gradually been consolidated as a political space for discussion and submission of proposals of interest in the human and social science areas. An important step in this direction was the implementation of the proposal of a working group, under the direction of the National Council for Scientific and Technological Development (CNPq), to discuss and design a policy of Science, Technology and Innovation for the Human, Social and Applied Social Sciences (GT-CNPq). The proposal was presented and discussed at the Symposium of Human and Social Sciences in the Contemporary Policies for Science, Technology and Innovation, held on August 20, 2014, in the CNPq headquarters, and later sent by the Forum to the president of CNPq. The proposed Working Group was actually created by Regulation CNPq/PO-360/2014 of 19 November 2014. A second petition filed at the Symposium led to the creation of a Human and Applied Social Science Board (approved by the CNPq Executive Council on November 26, 2014).

\section{National Research Ethics Commission/CONEP creates a working group to address the issues of human and social sciences}

The creation of a working group with the aim of developing a specific resolution for the human and social sciences (hereinafter referred to as the CHS Resolution) took place at a meeting held in the CONEP headquarters, in Brasilia, on August 14, 2013. The creation complied with the provisions of CNS Resolution 466/12 in which Chapter XIII recognized the existence of ethical specificities inherent in research in the human and social sciences. The same Chapter provides for the development of a new resolution that effectively addresses these specifications. The associations that had actively participated in the public consultation on the revision of Resolution 196/96, ANPEPP, ABA and ABEPSS, were invited to this initial meeting. The initial group was subsequently expanded through a general invitation sent by CONEP to research associations, to which 20 organizations responded with an indication of their representatives for the GT-CONEP. In addition to representatives from the scientific associations, 10 other members directly connected to CONEP and/or other bodies related to the Ministry of Health participate in the CONEP-CHS on a continuous or sporadic basis. The coordination of the Working Group is performed by a member of CONEP.

The first phase of work of the GT-CONEP was completed at the end of 2014 with the development of the CHS draft Resolution. As foreseen by CONEP, the draft was initially discussed in the plenary session of CONEP and in a special Meeting of Research Ethics Committees/ ENCEP (Atibaia, São Paulo, November 2014). This completed the first stage of the critical appraisal of the proposal, providing space for the GT-CONEP to review it based on the reactions received. The construction schedule of the CHS Resolution states that the version reviewed by the GT-CONEP should now be referred for the assessment of scientific associations and the wider society through public consultation. At the end of this consultation, the draft must once again be returned to the GT-CONEP for review and then be forwarded to CONEP for reconsideration, before being submitted to the National Health Council for final approval and promulgation.

\section{Seeking a specific resolution for the humanities and social sciences}

Trends and challenges of various natures mark the progress of the preparatory work of a specific resolution for research in the human and social sciences. Especially striking challenges are issues related to: (1) the autonomy and scope of the CHS Resolution; (2) the assessment of level of risk as a criterion for the allocation of projects to different evaluation and processing procedures in the CEPs; (3) the relationship between risk assessment and vulnerability of the research participants; (4) variability in the procedures for obtaining and recording consent; and (5) confidentiality. The following sections examine each of these issues.

\section{Autonomy and scope of the CHS Resolution}

The entry into force of the CHS Resolution will inaugurate a scenario of coexistence between the new resolution, understood as the reference document for the analysis of research in the human and social sciences, and the current CNS Resolution 466/12 with its revisions and complementary resolutions. Among the many issues that can be raised given the scenario of coexistence of the two resolutions, two aspects have been the subject of vigorous discussions: (1) the autonomy of the CHS Resolution in the face of CNS Resolution 466/12; and (2) the scope of application of each, i.e., the criteria from which one or the other resolution would be chosen as the reference for the ethical analysis of each project.

Regarding the first point, the consolidated view in the GT-CONEP affirms the autonomy and sufficiency of each resolution. Each resolution is seen as a regulatory instrument sufficient for the review of research that it evaluates. This view thus excludes the possibility of any project being, simultaneously or successively, submitted to both resolutions. It also excludes the possibility that principles, requirements and/or procedures specific to Resolution ' $\mathrm{A}$ ' are imported or used in the review of project evaluated through Resolution 'B.' In operational terms, it is expected that, with the entry into force of the CHS Resolution, the Brazil Platform ${ }^{5}$ will pass through adaptations to allow, at the moment of registration in the Platform, each project to be alternatively directed for evaluation based on the current

The Brazil Platform is an electronic platform for transmitting all procedures related to the evaluation of the ethical aspects of the projects submitted for evaluation by the CEPs - from the initial registration of the project to the final emission of the authorization (http://aplicacao.saude.gov.br/plataformabrasil/login.jsf) 
CNS Resolution 466/12 or on the CHS Resolution. Thus, an instrument for the registration for projects in the Brazil Platform is being prepared.

Regarding the scope of application, the understanding is that it is up to the researcher responsible for the study to direct the project for review based on one or the other resolution. Nature and characteristics of the problem investigated and methodological perspective adopted are the key criteria for this choice. This perspective therefore provides the possibility for projects recognized as belonging to the same field of knowledge to have their ethical aspects evaluated based on different resolutions (CNS Resolution 466/12 or the CHS Resolution). Adopting nature of the problem and method of investigation as benchmarks (and not the area or field of knowledge in which the project is formally included) is particularly relevant to research in psychology, given its dual intersection with the human and social sciences and the health sciences.

Relationship between risk level of the project and type of review

A second striking aspect of the CHS Resolution concerns the creation of different procedures for evaluating the ethical aspects of projects. The allocation to review procedures would basically be defined in accordance with the evaluation of the risk level attributed to each project.

The discussion of inherent risks in research is a controversial issue among researchers in the human and social sciences, and commonly generates strong reactions and marked divergences. On one hand, there is widespread recognition that research in human and social sciences is not, in itself, without risks. On the other hand, the premise held by Resolutions/CNS that all research involves risks to participants, or at least risks beyond those considered inherent in their existence and everyday lives, is considered debatable. Admitting the reasonableness of both sides of the debate, it is understood that different levels of risk (if any) are presented in different projects, which would therefore require ethical review procedures with greater or lesser degrees of detail and duration.

Four risk levels and four corresponding evaluation procedures have so far been proposed (provisional names): (1) minimal risk (almost nonexistent) that would correspond to the minimum evaluation, performed from the project registration instrument in the Brazil Platform, with immediate liberation; (2) low risk, which would involve a brief review by one of the reviewers of the CEP, without the need for the project to be sent for discussion by the CEP; (3) moderate risk, which would require a more detailed review by the CEP; and (4) high risk, which would involve review by CONEP, or CEPs especially accredited for this. In the operational plan, it is expected that the characterization of the risk level of each project will be given based on the responses of the researcher to the registration instrument and through the characterization of the project, mentioned above.

\section{Vulnerability}

The need to characterize different risk levels associated with different studies is an enormous challenge that is involved in the current construction process of the CHS Resolution. The advance in this analysis requires discussion regarding how to define and identify conditions of vulnerability that affect the research participants. How to define vulnerability and identify different conditions under which this can occur? What relationships can be established between vulnerability, incapability and risk? How to conduct the procedure for obtaining and registering consent in studies with vulnerable and incapable subjects? How to guarantee the necessary respect to subjects' freedom of decision and, on the other hand, ensure the viability of the research? These are complex issues that require much more than single and standard responses.

A particularly critical point to consider is the necessary distinction between vulnerability and incapability in the legal sense, and vulnerability related to research ethics. While, in the first case vulnerability and incapability are categories that refer to diverse and/or adverse conditions in the lives of individuals (physical or emotional immaturity, the presence of disease, conditions of detention, etc.), within the context of research vulnerability relates to the procedures and aims of the study. The relative independence of these two perspectives can be understood when, for example, research with babies is considered. From a legal point of view, babies are considered incapable. However, to be considered legally incapable does not necessarily imply vulnerability in relation to the aims and/or procedures of a study. It seems plausible to argue that observation procedures and the recording of adult-child interactions in everyday contexts, typically used in research with babies, do not expose the child to vulnerabilities that may be associated with these procedures. Mutatis mutandis, many other situations could be highlighted in the research of other issues involving child-participants.

Finally, however no less important, is the need to avoid using extreme cases of procedures that aggregate vulnerability and risks for participants as a reference in the definition of standards for projects in general. For example: cases in which procedures used in research in the classroom that have eventually entailed vulnerability to the study target children should not constitute sufficient grounds to place the perspective of suspicion on all classroom research. Extreme cases should not be a general rule for creating a thorough and exhaustive evaluation process, as this could compromise research in the area.

\section{Consent}

The guarantee to the individual of freedom to consent or not to participate in a study is one of the most basic and important ethical aspects of research. The broad agreement regarding the importance of consent in scientific investigation does not, however, stop the practical management of this issue being one of the most delicate and problematic points. 
This important issue is one of the major differences between research methods practiced in the human and social sciences and those typical of biomedicine. It is considered, for example, that the standard way of obtaining consent previewed in CNS Resolution 466/12, through a written document, with minute details of the study procedures, would not apply to a number of research contexts in the human and social sciences. Especially with regard to methodological traditions in which the research is seen, above all, as trust established between researcher and researched, and consent as a process that runs through all of the research activity. In the discussion of this issue, it is common to cite, for example, research on the so-called transgressor behaviors. In such cases, the express consent through signing a consent form would amount to an explicit confession of committing a transgression, with consequent harm to the participant. Another example would be, cases of the use of so-called 'covert research,' in which the prior explanation of the study objectives and/or procedures would substantially change the situation or phenomenon that it aims to study.

The conclusion that arises from examples such as these is that how and when to obtain the consent of the participants are issues that concede and require multiple responses, depending on the nature of the problems and the particular conditions of the studies. Whatever the case, the ongoing discussions on the GT-CONEP have been concerned with the necessary distinction between obtaining consent on the one hand, and registering the consent on the other. The first question refers to how, where, when the consent of the participant can and should be obtained and even whether this is necessary; the second involves decisions regarding the manner in which consent can and should be registered. For example, consent could be recorded through written text, as speech and/or image recording, through thirdparty testimony or through other arrangements, as may be considered appropriate. In the previously mentioned case of transgression behavior studies, the implied conclusion seems to be that the absence of registration (rather than the registration) would be the procedure that could effectively ensure the protection of the research participants.

\section{Confidentiality}

Confidentiality is directly associated with those points previously mentioned and also dealt with in a standardized and universal way. In the current research ethics regulation system, confidentiality is a right provided to participants of any research. However, situations in which the problem of confidentiality should receive different treatment can be distinguished here. For example, situations can be cited in which the participant wishes to be identified, or situations in which the identification of the participants, far from having undesirable risks, would implicate or enable their empowerment. An example of the latter are the studies that provide participants with training to obtain skills that eventually equip them for the labor market. Another would be cases in which the research objectives and procedures lead to the verification of cases of basic rights violations of the person, where the breach of confidentiality - rather than its maintenance - would become an ethical and/or even legal imperative for the researcher.

\section{Final Considerations}

The considerations presented highlight two crucial points that challenge the construction work of the CHS Resolution: (1) the clear characterization of what is meant by 'research in the human and social sciences' - and that would, therefore, have its ethical review regulated from the perspective of the specific resolution for the human and social sciences; and (2) the definition of parameters from which different risk levels in studies can be identified. Aspects, such as vulnerability of the participants, possibility and conditions for obtaining informed consent and registration, and confidentiality are seen as critical for this identification.

It should be noted that, despite the advances identified in the current work of developing the CHS Resolution, problems that initially prompted the formation of the Forum of Human, Social and Applied Social Science Associations still need to be solved. Such problems include the discussion of inadequacies and nuisances generated, for Brazilian researchers in the human and social sciences who are conducting research involving human subjects, by the inappropriate management of the CNS. By way of comparison and contrast, the ethical regulation of research involving non-human animals is based on the Arouca Law (Law 11.794 of October 8, 2008) and normative resolutions of the National Council of Animal Experimentation Control (CONCEA) governing the creation of Ethics Committees for Research with the Use of Animals (CEUAs) and the procedure of Institutional Accreditation for Activities with Animals in Teaching or Research (CIAEP). All these instruments operate under the supervisory aegis of the Ministry of Science, Technology and Innovation. ${ }^{6}$

Finally, in the more local context of psychology, there is the challenge of expanding the reflection and participation of researchers in these issues and, once the different co-existing views in the area have been considered, reaching positions that address the specificities of the different methods and procedures in use. Even if consensus is not reached, it is essential to justify the legitimacy of the positions of ANPEPP given the dialogue with the CEP-CONEP System and with the human and social sciences with which psychology has shared points and differences to consider. The legitimacy alluded to above can only be constructed from the sharing of information and the establishment of reflections and debates in the members/programs, and in the collective of ANPEPP.

\footnotetext{
http://www.mct.gov.br/index.php/content/view/310553.html.
} 


\section{References}

Borges, L. de O., Barros, S. C., \& Leite, C. P. do R. L. M. (2013). Ética na pesquisa em psicologia: Princípios, aplicações e contradições normativas [Ethics in research in psychology: Principles, applications and normative contradictions]. Psicologia: Ciência e Profissão, 33, 146-161.

CONEP (2014). Resolução n.466, de 12 de dezembro de 2012. Retrieved from http://conselho.saude.gov. br/resolucoes/2012/ Reso466.pdf

Fleischer, S., \& Schuch, P. (Eds.). Ética e regulamentação na pesquisa antropológica [Ethics and regulation in anthropological research]. Brasília: Letras Livres: Editora UNB.

Guerriero, I. C. Z., \& Dallari, S. G. (2008). A necessidade de diretrizes éticas adequadas às pesquisas qualitativas em saúde. [The need for adequate ethical guidelines for qualitative health research]. Ciência \& Saúde Coletiva, 13, 303-311.

Guerriero, I. C. Z., \& Minayo, M. C. de S. (2013). Physis: Revista de Saúde Coletiva, 23, 763-782.

Guerriero, I. C. Z., Schmidt, M. L. S., \& Zicker, F. (Eds.). (2008). Ética nas pesquisas em ciências humanas e sociais na saúde [Ethics in research in the human and social sciences in health]. São Paulo: Aderaldo \& Rothschild.

Leitão, S. (2010). Marcos na reflexão da ANPEPP sobre a ética em pesquisa com seres humanos [Milestones in reflection ANPEPP on ethics in research with human beings]. In: Associação Nacional de Pesquisa e Pós-graduação em Psicologia. XIII Simpósio de Pesquisa e Intercâmbio Cientifico (pp. 205-208). Fortaleza, CE. Retrieved from http:// www.anpepp.org.br/old/XIIISimposio/Anais \%2013\%20 Simposio\%20ANPEPP.pdf

Machado, A. C. A. (2012). Impacto da regulamentação brasileira sobre ética em pesquisa no trabalho de pesquisadores em psicologia [Impact of the Brazilian regulations about ethics in research in the work of researchers in psychology]. Unpublished master's thesis. Brasília: UnB.

Masiero, A. L. (2003). A lobotomia e a leucotomia nos manicômios brasileiros [Lobotomy and leucotomy in Brazilian mental hospitals]. História, Ciências, Saúde Manguinhos, 10, 549-72, maio-ago. Retrieved from http:// www.scielo.br/pdf/hcsm/v10n2/17750.pdf

Minayo, M. C. de S., \& Guerriero, I. C. Z. (2014). Reflexividade como éthos da pesquisa qualitative [Reflexivity as the ethos of qualitative research]. Revista Ciência e Saúde Coletiva, 19, 1103-1112.

Sarti, C., \& Duarte, L. F. D. (Eds.) (2013). Antropologia e ética: Desafios para a regulamentação [Anthropology and ethics: Challenges for regulation]. Brasília, DF: ABA.

The National Commission for the Protection of Human Subjects of Biomedical and Behavioral Research (1979). Belmont Report: Ethical principles and guidelines for the protection of human subjects of research. Retrieved from http://tinyurl. com/nys $18 x p$

Trindade, Z. A., \& Szymanski, H. (2008). O impacto dos comitês de ética-CEPs na atividade de pesquisa em psicologia [The impact of ethics committees - CEPs in the research activity in psychology]. In I. C. Z. Gurriero, M. L. S. Schmidt \& F. Zicker (Eds.), Éticas nas pesquisas em ciências humanas e sociais na saúde (pp. 280-302). São Paulo: Hucitec.

Received: September 01, 2014 Reviewed: March 03, 2015 Accepted: April 05, 2015 
Appendix 1:

Correspondence between names of entities in Portuguese and English.

\begin{tabular}{|c|c|c|}
\hline ACRONYM. & Português & English \\
\hline $\mathrm{ABA}$ & Associação Brasileira de Antropologia & Brazilian Anthropological Association \\
\hline ABEPSS & $\begin{array}{l}\text { Associação Brasileira de Ensino e Pesquisa em } \\
\text { Serviço Social }\end{array}$ & $\begin{array}{l}\text { Brazilian Association of Education and Research } \\
\text { in Social Work }\end{array}$ \\
\hline $\mathrm{ABPD}$ & $\begin{array}{l}\text { Associação Brasileira de Psicologia do } \\
\text { Desenvolvimento }\end{array}$ & $\begin{array}{l}\text { Brazilian Association of Developmental } \\
\text { Psychology }\end{array}$ \\
\hline ABRAPEE & $\begin{array}{l}\text { Associação Brasileira de Psicologia Escolar e } \\
\text { Educacional }\end{array}$ & $\begin{array}{l}\text { Brazilian Association of School and Educational } \\
\text { Psychology }\end{array}$ \\
\hline ABRAPSO & Associação Brasileira de Psicologia Social & Brazilian Association of Social Psychology \\
\hline ABRASCO & Associação Brasileira de Saúde Coletiva & Brazilian Association of Public Health \\
\hline ANPEPP & $\begin{array}{l}\text { Associação Nacional de Pesquisa e Pós- } \\
\text { Graduação em Psicologia }\end{array}$ & $\begin{array}{l}\text { National Association of Research and } \\
\text { Postgraduate Studies in Psychology }\end{array}$ \\
\hline ANPOCS & $\begin{array}{l}\text { Associação Nacional de Pós-Graduação e } \\
\text { Pesquisa em Ciências Sociais }\end{array}$ & $\begin{array}{l}\text { National Association of Postgraduate Studies } \\
\text { and Research in Social Sciences }\end{array}$ \\
\hline CEP & Comitês de Ética de Pesquisa & Research Ethics Committee \\
\hline CEUAs & Comitês de Ética no Uso de Animais & $\begin{array}{l}\text { Ethics Committees for Research with the Use of } \\
\text { Animals }\end{array}$ \\
\hline CFP & Conselho Federal de Psicologia & Federal Council of Psychology \\
\hline CIAEP & $\begin{array}{l}\text { Credenciamento Institucional para Atividades } \\
\text { com Animais em Ensino ou Pesquisa }\end{array}$ & $\begin{array}{l}\text { Institutional Accreditation for Activities with } \\
\text { Animals in Teaching or Research }\end{array}$ \\
\hline CIOMS & $\begin{array}{l}\text { Conselho de Organizações Internacionais das } \\
\text { Ciências Médicas }\end{array}$ & $\begin{array}{l}\text { Council for International Organizations of } \\
\text { Medical Sciences } \\
\end{array}$ \\
\hline CHS & Ciências Humanas e Sociais & Human and Social Sciences \\
\hline $\mathrm{CNPq}$ & $\begin{array}{l}\text { Conselho Nacional de Desenvolvimento } \\
\text { Científico e Tecnológico }\end{array}$ & $\begin{array}{l}\text { National Council for Scientific and } \\
\text { Technological Development }\end{array}$ \\
\hline CONCEA & $\begin{array}{l}\text { Conselho Nacional de Controle de } \\
\text { Experimentação Animal }\end{array}$ & $\begin{array}{l}\text { National Council of Animal Experimentation } \\
\text { Control }\end{array}$ \\
\hline CONEP & Comissão Nacional de Ética em Pesquisa & National Research Ethics Commission \\
\hline $\mathrm{CNS}$ & Conselho Nacional de Saúde & National Health Council \\
\hline ENCEP & $\begin{array}{l}\text { Encontro Nacional dos Comitês de Ética em } \\
\text { Pesquisa }\end{array}$ & $\begin{array}{l}\text { National Meeting of Research Ethics } \\
\text { Committees }\end{array}$ \\
\hline GT & Grupo de Trabalho & Working Group \\
\hline IC & $\begin{array}{l}\text { Termo de Consentimento Livre e Esclarecido } \\
\text { (TCLE) }\end{array}$ & Informed Consent \\
\hline MCTI & Ministério da Ciência, Tecnologia e Inovação & Ministry of Science, Technology and Innovation \\
\hline OMS, WHO & Organização Mundial da Saúde & World Health Organization \\
\hline RENETO & $\begin{array}{l}\text { Rede Nacional de Ensino e Pesquisa em Terapia } \\
\text { Ocupacional }\end{array}$ & $\begin{array}{l}\text { National Network of Education and Research in } \\
\text { Occupational Therapy }\end{array}$ \\
\hline
\end{tabular}

